\title{
LEAN PHILOSOPHY IN STRATEGIC SUPPLY CHAIN MANAGEMENT AND VALUE CREATING
}

\author{
Bülent SEZEN \\ Sema ERDOGAN \\ Gebze Institute of Technology, Turkey
}

"The battlefront in today's competitive wars, and the ultimate core competency of a business organization, is the design of the supply chain." - Charles H. Fine, Clockspeed

\begin{abstract}
After the Second World War, while oil crises rise all over the world, managers tried to find out the secret of Japanese strategic management decisions. For the Japanese, who originated a new organizational form, which employed the lean production methods, as known as Toyota Production System; the customer satisfaction and high quality are the competitive advantages. Besides for the western managers, lean production was a scary thing, "when an industry is dominated by mass producers" (Cooper, 1995). From the history up today, this paper aims to introduce the lean philosophy in the strategic supply chain management and its processes. Nowadays the lean tools are used to reduce wasteful activities across the supply chain.
\end{abstract}

Keywords: Lean Production, Lean Philosophy, Strategic Supply Chain Management, Value Creating.

\section{INTRODUCTION}

The main purpose of the lean production is to eliminate the waste in every step of work processes in the enterprises. It comes from the Toyota Production System, which was examined by the Massachusetts Institute of Technology (MIT) in USA and introduced in the name of "lean production system" in the literature by Womack et al. (1990); they used the term "lean production" to contrast Toyota with the Western 'mass production' system (Holweg, 2007).

Actually in the development of the term "lean" was firstly used by Krafcik (1988) to describe the system of Japanese, who worked at International Motor Vehicle Program Research Affiliate Team in MIT, too. According to them the system was "lean", because it can do more with less.

Lean is a systematic approach to enhancing value to the customer by identifying and eliminating waste (of time, effort and materials) through continuous improvement, by flowing the product at the pull of the customer, in pursuit of perfection (Manrodt, 2008). In this study the authors aim to focus on the importance and history of the lean production in the strategic supply chain management and their implementations, so in the next sections first the history, and then the principles and strategies of the lean applications in supply chain will be introduced. 


\section{The History of Lean Production}

Today lean production is a well-known philosophy, which fights for eliminating waste in the firms. After the Second World War, when Toyota was aware of this opportunity to reach efficiency at its production system, the mass production was more popular all over the world.

Taiichi Ohno, one of the founders of "the Toyota Way"; pointed out in his distinguished book about Toyota, until the oil crisis (in 1970s) there was little interest in what Toyota was doing (Ohno, 1996). Thus, it seems that Toyota was well aware of its productivity advantage at the time (Holweg, 2007). McPhee and Wheeler (2006) took the history of the Toyota system to show the importance of supply chain management in lean production:

"Toyota has invested significant resources into a set of activities for creating and supporting the supplier network, including developing supplier networks like the Bluegrass Automotive Manufacturers Association in the US and providing senior-management support to suppliers to help them solve production problems through Toyota's Operations Management Consulting Division. The result is a network of suppliers that provides more value to the supply chain than the suppliers of Toyota's competitors, allowing Toyota to capture more value from its product and develop a competitive advantage. This corporate mindset also applies to Toyota's downstream relationship-building through dealers to purchasers."

When the benchmark studies between Toyota and GM started in USA, the practitioners described the gap between the Western World and Japan and they also measured the size of the gap (Holweg, 2007). After these exploratory researches, which include the MIT projects benchmarking "the national system" (American) also with Honda, Nissan and Mazda, International Motor Vehicle Program (IMVP), New United Motor Manufacturing (NUMMI), etc., like a conclusive report the famous book "The Machine That Changed The World" was published by Womack, Jones and Roos (1990) from the MIT-IMVP Team. The "Machine" book introduced "the fall of mass production" and in contrast "rise of lean production" in the automotive industry and described the lean enterprises.

Although lean production was developed through the study of the Japanese automotive industry, Womack and Jones argue in the following studies that its approaches and the way of thinking can transcend cultural and industrial divides (McIvor, 2001). They also mentioned in their later-dated book (Womack and Jones, 2005) that lean production can be applied in every company, industry and country if it is taken seriously.

It took several years before wider academic and practitioner circles would pick up on the topic (Holweg, 2007), by the time the buyers and suppliers have to work harder to reduce the costs of products or services in the competitive area. And recently, the lean principles were defined and adopted by many different industries. Henceforth the new generation of the way of operations is based on the "pull" system and the traditional "push" supply chain system was eliminated after the lean production (Figure 1-2).

Figure.1 - "Pull" or "Demand" System (adopted from Blanchard et. al, 2008)

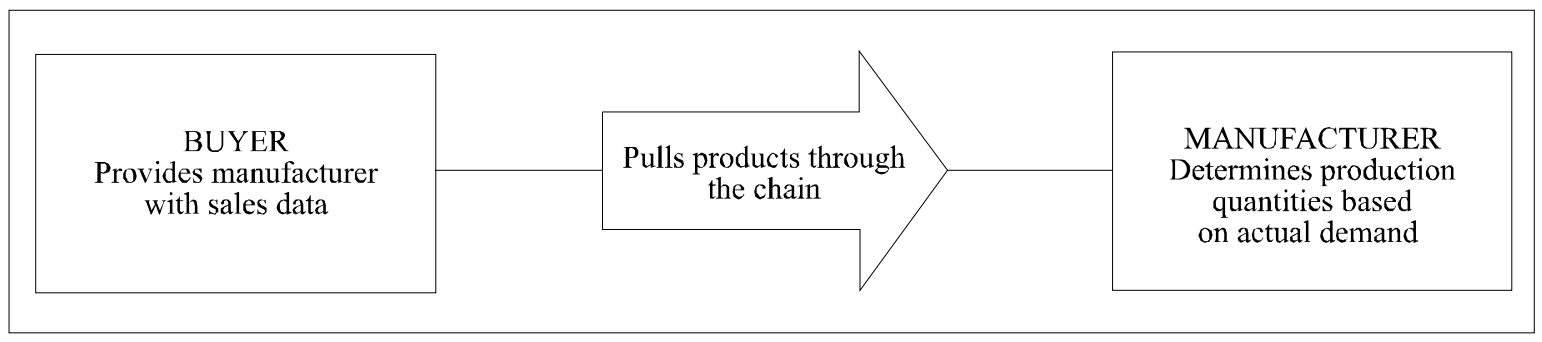

Figure.2 - Traditional "Push" Supply Chain System (adopted from Blanchard et. al, 2008)

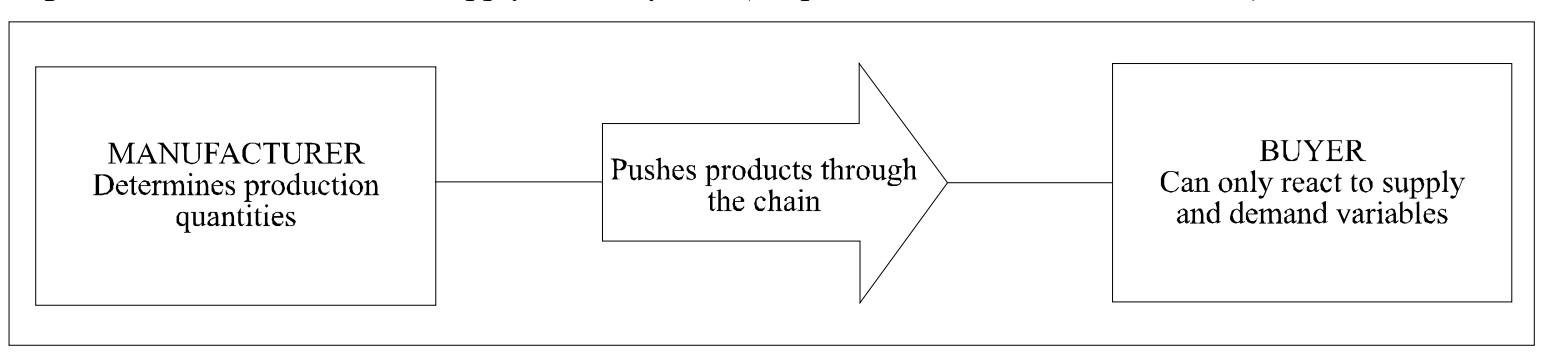


For the implementers, lean production principles are the way that enables to reduce the costs and with a little effort improves the efficiency and quality, which is the core meaning of the lean. For full effectiveness, the lean production system must be extended down through the supply chain (McIvor, 2001). All the key players of the supply chain must be in this play to reduce costs and to improve the quality and profits.

From academicians or practitioners' point of view lean production has become a philosophy in the strategic supply chain management. The Association for Operations Management (APICS) defines lean as a philosophy of production that emphasizes the minimization of the amount of all resources used in the various activities of the enterprise (Abbott et al., 2006).

\section{Lean Principles and Creating Value Stream}

Lean production is an integrated socio-technical system whose main objective is to eliminate waste by concurrently reducing or minimizing supplier, customer and internal variability (Shah and Ward, 2007). That's why the principles were identified like a recipe of effectiveness by Womack and Jones in the 90s first for the automobile and than for all industries. Lean principles were examined against the non-value adding activities. The book "Lean Thinking" introduced the five important principles of lean production in 1996. The five main organizing principles for creating a lean production system are (1) specify value by product, (2) identify the value stream for each product, (3) make value flow without interruptions, (4) let the customer pull value from the producer, and (5) pursue perfection (Hallam, 2001).

The benefits of this lean transformation are measured by metrics such as improved productivity (increases of 2 to 4 times), reduced inventories and work in progress (by as much as $99 \%$ ), and lead times for products that drop from weeks or months to minutes or days. All of these metrics point to an operating/management system that is considered beneficial to a company, and especially to its bottom line profitability (Hallam, 2001).

- Lean reverses the traditional logic"; it changes the processes with these principles;

- Only one ordering point in the provision stream

- Increase the frequency of delivery at every point

- Replenish only exactly what has just been sold or shipped

- And if possible; compress the provision stream to bring production and distribution closer to customers (Jones, 2005).
The logic behind lean thinking is that companies jointly identify the value stream for each product from concept to consumption and optimize this value stream regardless of traditional functional or corporate boundaries (McIvor, 2001). The lean enterprises collaborate with customers and suppliers and their relationships along the value stream are crucial to achieving "leanness" (McIvor, 2001). As Womack (2006) emphasized, "every process needs to create the right value, as defined by the customer." In a lean enterprise, the value creating means getting exactly what consumers really want; so, for an example, the customer can "pull" products from the manufacturer as needed. A win-win-win is possible in which providers, employees and consumers create lean solutions together (Womack\&Jones, 2005).

\section{Lean Supply Chain}

A lean supply chain is defined (Abbott et al., 2006) as a set of organizations directly linked by upstream and downstream flows of products, services, finances and information that collaboratively work to reduce cost and waste by efficiently and effectively pulling what is needed to meet the needs of the individual customer. This strategic decision to implement the lean production system is a managerial approach, but it affects from the top to the bottom in every stage of works, because the lean principles enable the employers to have the authority. In application for example, the employers ask five "why"s to solve the problem when a machine breaks down.

A lean supply chain includes a value stream through the customers and the suppliers have to play a strategic role to achieve a lean production system. As an example, when the lean system set between Tesco and its cola supplier; in 1996 the level of service was 98.5 \% compared with the level of service $99.5 \%$ in 2005 after the lean solution. There was also five storage locations between bottler and customer in 1996, and after lean supply chain solution there were two storage locations in 2005 (Womack, 2005). The result of Tesco case was the highest availability, lowest stock levels and the smoothest order signals (Jones, 2005).

The notion here is that buyers and suppliers are locked together in long-term, obligatory relations as distinct from the historical Western model of short-term competitive relations where contracts are awarded largely on the basis of price (McIvor, 2001). In opposite to the out-of-fashion Western management style, the price competition will be reflected to the cost reduction through the lean supply chain management in the long-term.

Actually, as Barla $(2003 ; 451)$ displayed the lean 
production is not a prerequisite to apply lean supply in a firm. In order to achieve a lean supply chain, it is necessary to apply the following tactics:

- regarding suppliers as an extension of the internal manufacturing process and cultivating them as long-term business partners;

- establishing long-term purchasing and supply commitments;

- improving communications with suppliers;

- involving suppliers in early stages of new product planning;

- using supplier expertise to improve design manufacturability and reducing product cost (Barla, 2003).

The characteristic of the lean supply is getting the customers exactly what they want, providing value where they want and fulfilling the orders when they want with high quality and with lowest cost. Nevertheless, it is an interesting point in application of the lean processes that the success of the customer and supplier embracing collaborative relations is heavily dependent upon the attitudes of the people from both organizations who manage the relationship at the operational level (McIvor, 2001), therefore the lean supply chain integration must be transmitted properly in every level of employers. Kerr (2006) pointed that "it is not necessary to wait for a green light from the top, any manager can begin with a small-scale analysis of what an operation would look like if it could be perfectly leveled; that is, if the weekly output could be evenly spread out during each working day."

\section{Lean Supply Chain Management as a Strategy}

Lamming argues that lean supply cannot be achieved unless some kind of close relationship, built upon mutual trust and openness is present, which is not compatible with an arm's length strategy (Lamming, 1993 in McIvor, 2001). According to this strategy, the customers turn into partners and adopt a view of "being in the same boat". As Toyota realized, optimizing a part of the process is different from optimizing "the whole", that's why the customers' and suppliers' opinions had to be included in every change decision (Abbott et al., 2006).

As a firm strategy the terms lean production and supply chain management must be clearly understood. Comparing lean and supply chain management is given in Table 1 to introduce the focus of each system.

So, the two systems engaged around two major goals: 1) reducing the costs and non-value-add activities, 2) optimizing time. Lean supply chain dimensions can change firm by firm, but the core aim of this lean strategy does not change. Leanness must sound for customer or supplier the same meaning, that is, fighting against waste and non-value adding activities through cost reduction. Despite the difficulty of implementing a lean system; the beauty of the lean philosophy is that it also focuses everyone on what matters- on exactly what the customer needs (Kerr, 2006).

Lean provides a set of tools and an operating philosophy that provides a structure for thinking beyond the short term. The emphasis on waste and cost reduction is holistic, and should not be limited to a single partner in the supply chain. Changing the culture to enable greater sharing of data - and trustis critical (Abbott et al., 2006). In competitive and increasingly global industries, suppliers who prosper will be the ones that can achieve world class performance regardless of the orientation of their customers (McIvor, 2001).

In this approach, for the lean enterprises the customer satisfaction and high quality are the competitive advantages, when the firms decide to handle with this long-term oriented change management with implementing the lean principles. The managers and also the change agents must beware of this dynamic system with high level of collaboration through the supply chain.

\section{CONCLUSION}

After the Japanese experiences in automobile industry, the lean production system (as known as Toyota Production System) was examined by Western academicians in MIT in International Motor Vehicle Program. When the term "lean" was popular in this area, the academicians and practitioners realized that it could be implemented to the other sectors, too.

Table.1 - Comparing Lean and Supply Chain Management (Manrodt, 2008)

\begin{tabular}{|l|l|}
\hline Lean Production & Supply Chain Management \\
\hline Focus on reduce waste and non-value-add activities & Goal is reduced lead-times/cost through various methods \\
\hline Traditional focus and success primarily with optimizing shop floor & Focus to optimize across supply chain partners \\
\hline Uses a set of structured tools & $\begin{array}{l}\text { Applies Lean tools as well as leverages other tools } \\
\text { (Sig Sigma, TQM, etc.) }\end{array}$ \\
\hline Emphasis on no inventory through "continuous flow" & Emphasis on minimizing inventory through various techniques \\
\hline
\end{tabular}


As a management strategy, the lean production system fits to supply chain management, which focuses to optimize the efficiency in the work progresses. Lean production is an application in or intra-firms that enable the managers and also employers to manage reducing waste and cost. It can be implemented through some tools like Kanban, JIT, TPM, 5S, etc. The tools can also fit to the whole supply chain, which is integrated to each key player (customers and suppliers).

Today the lean tools are used to reduce wasteful activities across the supply chain. It is an opportunity, when the companies need to develop new strategies in today's competitive area, that the lean production system can bring new solutions. The solutions address the business needs, not just consumers' product needs; it can be the right products, the new data flows, etc; so it is a new approach and a new mindset.

In conclusion, the lean approach brings the enterprises a value stream, which is called a business model. To reach high quality and customer satisfaction; the whole supply chain and each every chain implements the lean principles to have a competitive advantage and to reduce costs. For all the parts of business area, the buyers and sellers want the same thing: lower costs with high quality. So the lean production can give them the lower costs through eliminating waste; this is the main purpose of lean philosophy.

\section{REFERENCES}

Abbott, Jeff, Manrodt, Karl B. and Vitasek, Kate (2006), Understanding the Lean Supply Chain: Beginning the Journey, 2005 Report on Lean Practices in the Supply Chain.

Barla, Semra Birgün (2003), A case study of supplier selection for lean supply by using a mathematical model, Logistics Information Management, 16 (6), pp.451-459.

Blanchard, Cherie, Comm, Clare L. and Mathaisel, Dennis F.X. (2008), Adding value to service providers: benchmarking Wal-Mart, Benchmarking: An International Journal, 15 (2), pp.166-177.

Cooper, Robin (1995), When Lean Enterprises Collide, Harvard Business School Press, Massachusetts, USA.

Hallam, Cory R.A. (2001), Lean Thinking - Banish Waste and Create Wealth in Your Organization, Book Review,

http://web.mit.edu/esd.83/www/notebook/Lean $\% 20$ Thinking.doc

Holweg, Matthias (2007), The genealogy of lean production, Journal of Operations Management, 25, pp.420-437.

Jones, Daniel T. (2005), "Get me exactly what I want", Frontiers of Lean Summit, October 31,2005.

Jones, Daniel T. (2007), The Invisible Opportunity, International Commerce Review, 7(1), pp. 32-44.

Kerr, John (2006), "What does "lean" really mean?", Logistics Management, 5.1.2006, www.logisticsmgmt.com.

Krafcik, John F. (1988), Triumph of the Lean Production System, Sloan Management Review, Fall 1988, pp.41-52.

Manrodt, Karl B., Vitasek, Kate and Thompson, Richard H. (2008), Lean Practices in the Supply Chain, Jones Lang Laselle 2008 Report, http://podcastfiles.am.joneslanglasalle.com/u/docs $/ 2$ 85.pdf

McIvor, Ronan (2001), Lean supply: the design and cost reduction dimensions, European Journal of Purchasing \& Supply Management, 7, pp.227-242.

McPhee, Wayne and Wheeler, David (2006), Making the case for the added-value chain, Strategy \& Leadership, 34(4), pp.39-46.

Ohno, Taiichi (1996), Toyota Ruhu (Çev: Canan Feyyat), Scala Yay., İstanbul.

Shah, Rachna and Ward, Peter W. (2007), Defining 
and developing measures of lean production, Journal of Operations Management, 25, pp.785-805.

Womack, James P. (2005), How Lean Consumption Transforms Manufacturing \& Supply Chain, Industry Week Smart Manufacturing Conference, Illinois.

Womack, James P. (2006), Lean Solutions, Jacksonville Lean Consortium, January 10, 2006, Florida.

Womack, James P. and Jones, Daniel T. (2005), Lean Solutions - How Companies and Customers Can Create Value and Wealth Together, Free Press, New York, USA.

Womack, James P., Jones, Daniel T. and Roos, D. (1996), Lean Thinking, Simon and Schuster, New York.

Womack, James P., Jones, Daniel T. and Roos, D. (1990), The Machine That Changed The World, Rawson Associates, New York. 